\title{
PLATÃO E GREGÓRIO DE NISSA
}

\author{
ÁLVARO CÉSAR PESTANA* \\ Seminário Bíblico Nacional
}

RESUMO: Um estudo comparativo do Fédon de Platão com o Diálogo da alma e da ressurreição de Gregório de Nissa. Análise do contexto histórico, dos personagens e de cada obra. Leitura sinóptica comparativa das obras. Discussão do uso da linguagem religiosa em prol da filosofia, e da linguagem filosófica a serviço da religião.

PALAVRAS-CHAVE: imortalidade da alma; diálogo; filosofia; patrística; Platão; Gregório de Nissa.

\section{Introdução}

Os diálogos de Platão foram imitados e adaptados por vários pensadores na história. Entre os escritores cristãos, Justino Mártir ${ }^{1}$, já no século segundo, utilizou-se desse gênero literário de Platão para expor a doutrina cristã. Homens como Metódio ${ }^{2}$ e Gregório de Nissa foram mais longe, não apenas usando o mesmo gênero literário, mas também construindo diálogos que são contrapartidas cristãs de obras de Platão.

"Estudo do Fédon de Platão em comparação com o Diálogo da alma e da ressurreição de Gregório de Nissa" se justifica tanto pelo desejo de melhor compreender cada uma das obras, como também por realizar uma leitura do Fédon pela ótica de Gregório de Nissa. Será possível apreciar a utilização posterior da filosofia e da obra de Platão por um autor cristão.

O objetivo desta comunicação é o de realizar uma leitura da obra de Platão através de subsídios da leitura da obra de Gregório, observando as concordâncias e discordâncias entre ambas, sempre procurando respeitar o sentido original de cada documento. $\mathrm{O}$ alvo é obter uma leitura do Fédon por um leitor de Gregório de Nissa. 


\section{Platão e Gregório de Nissa}

PLATÃO, filosofo ateniense do séc. IV a.C. (429-348 a.C.), cuja obra consta de diálogos e cartas, marcou profundamente a teologia cristã em suas discussões sobre a natureza da divindade, da criação e da alma (Colvin, 1990, p. 737).

A filosofia de Platão voltada ao transcendente (Hatch, 1995, p. 241) tornou-se uma excelente ferramenta e um fértil campo de trabalho para os pensadores cristãos, preocupados em explicar justamente a transcendentalidade de seu Deus e de outros aspectos de sua religião. A frase de Numênio ${ }^{3}$ : "Quem é Platão senão Moisés falando ático", citada freqüentemente ${ }^{4}$, representa bem o espírito no qual boa parte do pensamento platônico foi avaliado pelos cristãos antigos. Justino Mártir afirmava que "os ensinos platônicos não são estranhos aos de Cristo, apesar de não serem similares em todos os aspectos" ${ }^{5}$ e considerava-os como preparatórios para a revelação cristã (Diálogo com Trifo, 2.3-6).

GREGÓRIO DE NISSA, bispo cristão na Capadócia no séc. IV d.C. (331/40-395 d.C.), cuja obra consta de tratados, sermões, cartas e diálogos, é um leitor de Platão, profundamente influenciado por ele. "Nenhum dos 'pais' do quarto século fez tão extensivo uso da filosofia como fez Gregório. Platonismo é o principal sistema filosófico que moldou sua teologia" (Brauer, 1971, p. 377).

Platão, contudo não é e nem poderia ser a única influência de Gregório. As três grandes tradições se interpenetram na bagagem cultural e religiosa de Gregório: a cultura clássica, a inspiração bíblica e a especulação judaico-cristã (Pacheco, 1983, p. 49).

Nascido em família cristã e influente na Capadócia, foi educado tanto por seus irmãos Basílio ${ }^{6}$ e Macrina ${ }^{7}$, como também foi um autodidata eficiente. Gregório, ao contrário dos outros dois Grandes Capadócios $^{8}$, não teve a chance de estudar em Atenas9. Talvez sua genialidade advenha justamente desta "falha" educacional: recebendo apenas um conhecimento básico dos Clássicos, não foi intimidado pelas interpretações de outros, mas usou seus dons intelectuais de modo original (Malherbe; Ferguson, 1978, p. 4).

No passado Gregório foi subestimado como administrador e como retórico em relação a Basílio de Cesaréia e a Gregório de Nazianzo que destacaram-se respectivamente nestas áreas (Hamman, 1985, p. 159; González, 1992, p. 301). O 
Bispo de Nissa, contudo, sempre foi reconhecido como o pensador mais profundo e original dentre os Três Capadócios (Balás, 1990, p. 401; González, 1992, p. 302).

Sua carreira eclesiástica começou cedo como leitor, mas rejeitou a vida monástica, casando-se e atuando como professor de retórica, como seu pai. Aceitou com relutância o bispado em Nissa em 372. A morte de seu irmão e professor Basílio em 379 marcou profundamente sua carreira cristã, forçando-o a assumir atuação e postura mais visíveis (Figueiredo, 1989, p. 71).

Atuou decisivamente no Segundo Concílio Ecumênico em Constantinopla (381 d.C.) que assinalou o triunfo da ortodoxia trinitariana. Na ocasião, seu nome figurou ao lado dos bispos de Alexandria e de Constantinopla como representantes do "padrão da fé cristã". A partir de 385 até a sua morte, passa a ter menos influência, dedicando-se mais à vida espiritual (Malherbe; Ferguson, 1978, p. $x v$-xvi).

Platão influenciou Gregório, tanto por leitura direta de suas obras como pelo Médio Platonismo ${ }^{10}$ e Neoplatonismo ${ }^{11}$. Outras influências filosóficas se percebem em suas obras ${ }^{12}$, mas embora o ambiente acadêmico de seu tempo fosse caracterizado "pelo sincretismo das épocas de decadência" (Pacheco, 1983, p. 49), ele mesmo não era um eclético. Guiando-se pelas Escrituras Sagradas e por seu pensamento, todas estas influências tornam-se convergentes em sua filosofia (id., ib., p. 65).

Platão e sua filosofia estão na base das principais alavancas do pensamento do Bispo de Nissa. "A distinção entre o mundo sensível e inteligível, ... a noção de imutabilidade como perfeição, a dimensão ascensional da vida espiritual, a identificação do Ser e do Bem, o caráter negativo do mal, a teoria da participação, o ser à imagem..." (id., ib., p. 53) todos estes aspectos fundamentais do pensamento filosófico de Gregório estão apoiados em Platão. Gregório foi "o filósofo da igreja e transmutador do platonismo para dentro da doutrina cristã" (Cherniss, 1971, p. 3). Cherniss chega a afirmar que a familiaridade de Gregório com os escritos de Platão era tal que ele podia citá-los de memória (id., ib., p. 61).

\section{Fédone Diálogoda ahma e da ressurreição}

O Diálogo da alma e da ressurreição ${ }^{13}$ sempre tem sido reconhecido por sua afinidade com o Fédon. ${ }^{14} \mathrm{Na}$ tabela abaixo, estão esboçados algumas concordâncias e o contraste (em itálico) entre as obras. 


\begin{tabular}{|c|c|}
\hline FÉDON & $\begin{array}{l}\text { DIÁLOGODA ALMAEDA } \\
\text { RESSURREIÇÃO }\end{array}$ \\
\hline Leito de morte de Sócrates. & $\begin{array}{l}\text { Leito de morte de Macrina, logo } \\
\text { após a morte de Basílio. }\end{array}$ \\
\hline Tema: imortalidade da alma. & $\begin{array}{l}\text { Tema: imortalidade da alma e } \\
\text { ressurreição. }\end{array}$ \\
\hline $\begin{array}{l}\text { O diálogo termina com a des- } \\
\text { crição da morte de Sócrates. }\end{array}$ & $\begin{array}{l}\text { Gregório reserva a descrição da } \\
\text { morte de Macrina para outra obra, a Vida } \\
\text { de Macrina. }\end{array}$ \\
\hline $\begin{array}{l}\text { Sócrates consola e instrui aos } \\
\text { que estão ao seu redor. }\end{array}$ & $\begin{array}{l}\text { Macrina consola e instrui seu } \\
\text { irmão e outros presentes. }\end{array}$ \\
\hline $\begin{array}{l}\text { Sócrates age como mestre do } \\
\text { grupo todo o tempo. }\end{array}$ & $\begin{array}{l}\text { Macrina é chamada de "mestra" } \\
\text { por todo o diálogo e realiza nele a fun- } \\
\text { ção de Sócrates para Gregório } \\
\text { (Momigliano, 1992, p. 337). }\end{array}$ \\
\hline $\begin{array}{l}\text { Várias pessoas participam do } \\
\text { diálogo, embora os principais sejam } \\
\text { Sócrates, Símias e Cebes. }\end{array}$ & $\begin{array}{l}\text { O diálogo ocorre apenas entre } \\
\text { Gregório e Macrina. }\end{array}$ \\
\hline $\begin{array}{l}\text { O narrador, Fédon, esteve pre- } \\
\text { sente no diálogo. }\end{array}$ & $\begin{array}{l}\text { O narrador, Gregório, esteve } \\
\text { presente no diálogo }\end{array}$ \\
\hline $\begin{array}{l}\text { O escritor, Platão, não está pre- } \\
\text { sente no diálogo. }\end{array}$ & $\begin{array}{l}\text { O escritor, Gregório, esteve pre- } \\
\text { sente no diálogo. }\end{array}$ \\
\hline $\begin{array}{l}\text { Cebes e Símias são os que le- } \\
\text { vantam objeções quando todos estão } \\
\text { convencidos. }\end{array}$ & $\begin{array}{l}\text { Gregório faz o papel de levan- } \\
\text { tar objeções num momento do diálogo } \\
\text { quando todos os presentes já se davam } \\
\text { por satisfeitos. }\end{array}$ \\
\hline $\begin{array}{l}\text { Sócrates infunde coragem aos } \\
\text { amigos desanimados em face da mor- } \\
\text { te iminente de seu Mestre }\end{array}$ & $\begin{array}{l}\text { Macrina anima e dá coragem a } \\
\text { Gregório, desanimado em face da morte } \\
\text { de Basílio e agora, da própria Macrina. }\end{array}$ \\
\hline
\end{tabular}


Apesar de todas as aproximações circunstanciais mencionadas acima, as obras possuem claras e profundas diferenças, como era de se esperar. Um dos principais recursos de argumentação na obra de Gregório é a citação das Escrituras. Como é natural em uma obra cristã, a Revelação conduz a razão. Quando a razão sozinha não alcança a verdade por sua própria força, a Revelação vem em auxílio da filosofia. Isto é característico da filosofia cristã (Pellegrino, 1938, p. 444).

Também a defesa da ressurreição que é a preocupação de Macrina na segunda parte do diálogo, não tem contrapartida no Fédon. Este fato, entretanto, não irá impedir que Gregório faça menção de idéias oriundas do Fédon em defesa da ressurreição.

Os mitos no Fédon, desempenham o papel de "dito provável" ou coisa que é possível que seja deste ou de outro modo. Não tem a força autoritativa que a Bíblia tem para Gregório e o público cristão.

Hegel é especialmente crítico com respeito à exposição mítica nos diálogos. Trata-a como algo "inevitável tratando-se dos primeiros começos da verdadeira ciência sob sua verdadeira forma” (Hegel, 1955, p. 150). Mas isto não o impede de avaliá-la como "uma fonte de equívocos e obscuridades" (id., ib., p. 151) Reconhece sua utilidade didática, mas critica sua utilização como inadequada ao discurso filosófico que deveria ser exposto de outro modo:

É certo que muitos filosofemas ficam mais compreensíveis graças à exposição mítica, mas isto não quer dizer que este seja o verdadeiro modo de expor a filosofia; os filosofemas são pensamentos que, para serem puros, devem ser expostos como tais e não de outro modo (id. ib.).

Assim, de acordo com Hegel, o mito que acompanha o final do Fédon, por exemplo, nada tem a ver com a filosofia de Platão. Nisto, as próprias palavras de Sócrates fazem distinção entre a dialética anterior e o mito que passa a narrar (Fédon 114 d 1-7).

Giovanni Reale cita estes comentários de Hegel para depois discordar dele mostrando que "o mito procura um esclarecimento no logos e o logos um complemento no mito". O mito, além de expressão de fé, é também apresentado como narração provável. "Falar por mitos ( $\mu \cup \theta 0 \lambda$ o $\gamma \varepsilon \hat{\imath} v)$ é exprimir-se por imagens, o que permanece válido em vários níveis na medida em que pensamos não só por conceitos, mas também por imagens" (Reale, 1994, p. 40-4). 


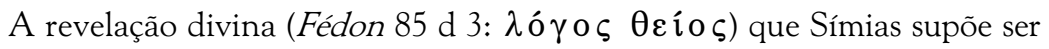
transporte mais sólido do que a jangada composta de tradições humanas (Fédon

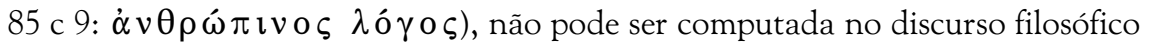
grego. Já no pensamento de Gregório é justamente a Escritura (De an. 64 b: ì

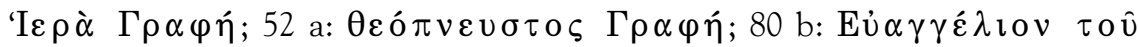
Ku $\rho$ íou) que desempenha o papel de revelação divina autoritativa e que resolve rápida e definitivamente uma série de questões ${ }^{15}$.

O recurso à matemática, tão caro a Platão, e presente na argumentação do Fédon (78 d; 100 e - 101 b; 103 e - 104 e) não existe na obra de Gregório de Nissa. Este é um aspecto da obra de Platão que não deixou traços na do nisseno.

\section{Personagens e contexto histórico}

O Fédon e Diálogo da alma e da ressurreição apresentam personagens cuja presença não somente produz os diálogos, mas dão indicações do sentido da obra.

Há, no Fédon, três níveis de contexto histórico discerníveis, como se fosse uma peça teatral dentro de outra, que por sua vez está sendo observada pelo público.

O primeiro nível de contexto está associado ao contexto histórico do dia da morte de Sócrates. Criton, velho amigo de Sócrates, pode ter sido uma fonte de Platão (Jeannière, 1995, p. 21), para narrar os acontecimentos do dia da morte do "mais justo dos homens". Outra fonte sugerida tem sido o próprio Fédon (Hackforth, 1992, p. 13). O próprio diálogo explica que a ausência de Platão no dia da execução foi motivada por uma doença (Fédon 59 b 10). A ausência de Platão tem sido indicada como forma de eximir-se da responsabilidade de oferecer completa exatidão sobre o ocorrido (Burnet, 1977, p. ix).

Os pensonagens que participam do diálogo neste nível são: Sócrates, Críton, Cebes, Símias, o próprio Fédon. Uma lista de outros presentes é apresentada logo de início (Fédon 59 b-c). Os grandes interlocutores contudo, são Sócrates de um lado e Cebes e Símias, tebanos, do outro. Críton participa do diálogo no início e no fim da obra, não interferindo na discussão em si mesma. Fédon aparece apenas no intervalo entre as objeções dos tebanos e a réplica de Sócrates a estes.

A versão de Fédon é o segundo nível do contexto histórico da obra. A conversa de Fédon e Enquécrates em Fliunte, ocorre na presença de um grupo 
de pitagóricos (Fédon 58 d 7; 102 a 8). Pela observação destes personagens apresentados (e também por outros motivos), Burnet considera-o como um diálogo "dedicado, por assim dizer, à comunidade pitagórica de Fliunte" (Burnet, 1994, p. 77, n. 3). Conforme observado por ele (id., 1977, p. ix-x), os interlocutores originais Cebes, Símias, Fédon e outros deveriam estar vivos quando o diálogo que leva o nome deste último foi escrito. Baseado neste fato, Burnet insiste em aceitar a historicidade de parte substancial dos fatos relatados e rejeitar explicações que considerem a obra inteira como "conversação imaginária". Hackforth assume um ponto de vista diferente afirmando que o que temos no Fédon é um Sócrates conscientemente platonizado (Hackforth, 1992, p. 3). A "autobiografia" filosófica que Platão faz Sócrates apresentar (Fédon 96 a) é reputada por muitos como sendo sua própria carreira, projetada sobre Sócrates.

O terceiro nível do contexto histórico é o de Platão no tempo da redação do diálogo. O Fédon é colocado entre os diálogos do período médio. Hackforth afirma que Platão estaria entre os trinta e cinco e os quarenta e cinco anos (Hackforth, 1992, p. 3). As influências pitagóricas no Fédon, para ele, "revelam a atração de Platão às opiniões religiosas e cosmológicas pitagóricas antes de sua visita à Magna Grécia" (id. ib. p. 6). A data sugerida por Hackforth é 387 a.C. (id. ib. p. 7). Como em todos os diálogos onde Sócrates é o principal protagonista, Platão faz o morto falar, dando voz àquele a quem queriam calar (Jeannière, 1995, p. 21). Os propósitos apologéticos do Fédon com respeito à pessoa e à filosofia de Sócrates, são enfatizados por Hackforth que considera a inclusão da obra entre dois encômios (89a, 116c), como reveladora de um de seus propósitos.

O Diálogo da alma e da ressurreição tem apenas dois participantes. Gregório e Macrina sua irmã mais velha e mestra espiritual. O momento em que o diálogo ocorreu é noticiado no primeiro parágrafo da obra (De an. 12 a). Seu irmão Basílio havia morrido (379 d.C.) e ele foi visitar sua irmã em busca de consolo. Entretanto, quando chega à antiga propriedade da família, agora transformada em um mosteiro, encontra sua irmã em seu leito de morte. Uma possível data para a publicação deste diálogo é 380 d.C. (Moore; Wilson, 1892, p. xiii).

Gregório idealiza Macrina, como tributo à influência que exerceu sobre sua vida, especialmente pela inclinação espiritual. Esta obra, juntamente com a biografia Vita Sanctae Macrinae, apresentam uma apologia da santidade daquela que ele vai chamar de mestra por todo o diálogo. Seu objetivo, além de louvar Macrina, parece ser estabelecer a doutrina cristã do além túmulo e da imortalidade da alma respondendo às criticas comuns de seu tempo contra a fé cristã. Sua resposta incluí sua defesa do traducianismo ${ }^{16}$ e da doutrina da Restauração 
Final ${ }^{17}$ de todas as coisas. A obra, portanto, tem caráter de apologia, pois é, em sua argumentação, dirigida aos de fora da igreja.

\title{
4. Estrutura de desenvolvimento e organização
}

Hegel grifou o fato do diálogo ser, por excelência, a forma da obra platônica. Vários aspectos se destacam, na opinião dele: 1. Cenografia; 2. Elemento dramático; 3. Sócrates, principal personagem; 4. Lugar concreto; 5. Pelo fato de Platão não intervir pessoalmente, qualquer elemento dogmático é retirado do diálogo; 6. Ausência de narrador externo; 7. Evitar o puramente expositivo; 8. Tom de nobre urbanidade: gente culta e cortês conversando com franqueza; 9. Trajetória dialética bela e conseqüente (Hegel, 1955, p. 146-8).

Destas observações de Hegel, várias delas oferecem paralelo e contraste com o Diálogo da alma e da ressurreição de Gregório de Nissa como trataremos adiante.

Numa avaliação de Platão, Hegel nota:

\begin{abstract}
A filosofia platônica não se anuncia por si mesma como um campo próprio e peculiar, ... mas sim que se ocupa, em parte, principalmente através de Sócrates, em considerações em torno das idéias correntes da cultura em geral, em parte se apresenta como um comentário das doutrinas dos sofistas e, em parte, versa também sobre os filósofos anteriores e, constantemente, traz ao colóquio, exemplos e modalidades tomados da consciência comum e corrente. Será inútil buscar uma exposição sistemática dos problemas da filosofia. ... Não obstante, está contido aqui, evidentemente, um espírito único, um ponto de vista determinado da filosofia, ainda que este espírito não se manifeste sob a forma determinada que nós exigimos. ... não haveria de plasmar-se em uma exposição científica sistemática até chegar a Aristóteles (Hegel, 1955, p. 149).
\end{abstract}

Esta não-sistematicidade da obra platônica contrastada por Hegel com a sistematicidade da obra de Aristóteles e até mesmo com a da religião cristã (id. ib. p. 136), fica evidente pela ausência de $\tau \dot{\varepsilon} \lambda \circ \varsigma$ (fim, destino) no sistema platônico. Conforme mencionado anteriormente, para Hegel, Aristóteles é o melhor representante de sistematicidade na filosofia antiga ${ }^{18}$. 
Esta opinião de Hegel, reflete sobretudo os seus pressupostos do que deve ser a forma adequada de expor a filosofia. Os diálogos platônicos e o de Gregório, apresentam uma unidade e coerência interna, sendo suficientes para o fim a que se destinavam. Esta forma de apresentação filosófica, que caracteriza Platão, ainda hoje permanece válida, na medida em que ainda é apreciada e utilizada.

No confronto entre o "Fédon" e o "Diálogo da alma e da ressurreição", o primeiro é, de longe, dramática e historicamente superior (Pellegrino, 1938, p. 444).

A leitura do Fédon revela uma construção artística difícil de encontrar no diálogo de Gregório. Este último mais parece uma dissertação, com raríssimas referências ao ambiente, à cena e a outras pessoas (De an. 68 a; 29 b-c). Não há discussão acalorada ou intervenções de terceiros: tudo é absolutamente sereno ${ }^{19}$. O Fédon, contudo, transpira a conversação animada e comum. A mestria de Platão em criar suspense e humor faz de sua obra uma peça da mais refinada dramaturgia.

Historicamente falando, o diálogo de Gregório e Macrina toma um curso que não pode ser verídico. Gregório, bispo cristão, não poderia realmente ter todas as dúvidas que apresenta no diálogo. De fato, as respostas de Macrina, repletas da filosofia platônica são, na verdade, colocadas em sua boca numa ficção dialogada. O gênio platonizante da família era Gregório. Mesmo que tivesse sido inicialmente instruído por Basílio e por sua irmã, ele foi muito além deles. Isto fica claro na comparação da obra dos irmãos capadócios.

Também há quem critique a historicidade do Fédon, afirmando que Platão coloca palavras na boca de Sócrates. O debate sobre a questão sempre vai existir, mas a possibilidade de historicidade no Fédon é sempre maior do que no Diálogo da alma e da ressurreição.

O grande argumento de Platão, para a imortalidade da alma, foi a morte de Sócrates! Sócrates mesmo é o melhor testemunho daquilo que a persuasão destas provas são capazes de produzir. No Fédon, mais do que em outros diálogos, "o leitor percebe que Platão confia mais no atual comportamento de Sócrates no momento da morte, do que em sua argumentação, para produzir convicção" (Temple, 1916, p. 81).

O Fédon tem um esboço argumentativo fácil de seguir. Discute-se o número dos argumentos ou chamadas "provas"

O primeiro argumento é o que poderíamos chamar de "Teoria dos Contrários" onde argumenta que assim como a morte vem da vida também a vida deve vir da morte completando o "ciclo dos opostos". O segundo argumento, 
auxiliar do primeiro é a "Teoria da Reminiscência" onde a imortalidade é afirmada pelo fato do verdadeiro aprendizado ser apenas recordação do que se aprendeu antes, em outra vida e realidade. $\mathrm{O}$ terceiro argumento baseia-se na "Teoria das Formas" e afirma a semelhança da alma com o divino e com as idéias, sendo, portanto, imortal.

Depois de expor sobre a purificação da alma, Cebes e Símias apresentam suas objeções. Símias acredita ser a alma apenas uma harmonia e portanto, que será destruída com a morte. Cebes objeta que uma alma preexistente pode vir a ser aniquilada.

Sócrates responde a Símias reduzindo seu argumento sobre ser a alma apenas uma harmonia ao absurdo. A resposta a Cebes é prefaciada pela explicação da necessidade de deixar os métodos científicos anteriores e utilizar a Teoria das Idéias. Justamente com esta teoria ele mostra que os contrários se excluem e portanto, aquilo que representa e dá vida ao corpo, a alma, não pode participar do seu contrário que é a morte, logo é imortal.

O ritmo dos argumentos no Diálogo da alma e da ressurreição é mais difícil de seguir por ser a argumentação menos cadenciada. Os discursos de Macrina são, em geral, mais longos do que as falas de Sócrates, e as objeções e questões de Gregório não permitem um esboço fácil. Não há "provas" facilmente enumeráveis e observáveis como no Fédon. Anotaremos a seguir, o ritmo do discurso.

O primeiro argumento em defesa da imortalidade da alma é o "argumento moral": se não há vida eterna, a virtude perde o valor.

Gregório objeta que o corpo composto, desfeito na morte, levaria ao desaparecimento da alma, pois se não está mais nos elementos, não existe. Macrina refuta dizendo que isto é ateísmo, pois Deus não se vê nos elementos, contudo existe. Ela afirma ser o homem um pequeno universo e portanto sua alma imaterial comanda o corpo material. Gregório, porém, insiste em dizer que o movimento é apenas resultado de uma "máquina orgânica" em funcionamento. Macrina responde que a máquina pressupõe uma Mente. Mas ele diz, se a alma não é percebida, o que é? Ela é como a Divindade, cuja existência não se nega. Não é idêntica mas semelhante a Deus, como uma cópia parece seu original.

Gregório então faz objeções baseado no fato da alma apresentar ira e desejo. Macrina responde que estes elementos não fazem parte da alma, mas são estados dela, são o "joio" da alma.

A questão então é: onde a alma dos mortos fica? Nos infernos? Macrina responde dizendo que a ela fica no mundo invisível. Gregório então objeta: se a 
alma se afasta dos elementos, como pode ocorrer depois a ressurreição? A resposta é que a alma recorda a quais elementos estava unida. A parábola do Rico e Lázaro interpretada platonicamente é usada para explicar o sofrimento das almas como processo de purificação.

Contudo, se não houver emoções no além, como haverá amor a Deus? Macrina responde que haverá atração a Deus pelo fato de similar atrair similar e não por desejo.

Macrina apresenta então a doutrina da ressurreição mostrando que ela concorda com certos conceitos pagãos, mas idéias como transmigração e rotação das almas são desmantelados.

Gregório então questiona sobre como e quando se forma a alma. Macrina afirma que podemos saber quando: na formação do corpo. Corpo e alma nascem juntos. A objeção sobre o número das almas é respondida pela exegese platonizante de um Salmo.

Gregório objeta que a ressurreição não vale a pena conforme o estado em que o corpo morreu. Macrina contudo afirma que a ressurreição é a restauração do homem à sua natureza original perfeita, como Deus o criou. Após a purificação do mal, todos contemplarão a Deus.

\section{Leitura sinóptica das obras}

Os pontos de contato entre o Fédon e o Diálogo da alma e da ressurreição serão explorados abaixo. Muitos deles são resultado de consciente alusão ao Fédon por parte de Gregório. Outros são passíveis de serem originados em outras obras de Platão e até em outros sistemas e obras filosóficas. Nosso alvo não é o de provar dependência direta ou determinar as fontes citadas por Gregório, mas apenas expor as aproximações das duas obras, seja por citação ou alusão, seja por aproximação casual.

A ordem de menção destas comparações será a do Fédon, sendo portanto, os parágrafos seguintes, comentários do Fédon ocasionados pelo seu uso no Diálogo da alma e da ressurreição.

Logo no início da sua argumentação, Sócrates defende a idéia de que o filósofo é um homem cuja única preocupação é preparar-se para morrer (Fédon 64 a), afirmando que somente com a morte é possível a contemplação do Belo e do Bem (Fédon 65 d - 67 b). Neste aspecto já ocorre uma diferença entre Platão e 
Gregório, pois para este último, é possível a contemplação do Belo ( $\pi \rho$ ò $\varsigma \tau \hat{\alpha} \alpha$

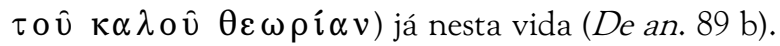

Esta diferença anuncia os dois diferentes métodos e sentidos da purificação de que tratam os dois diálogos. No Fédon, purificação é conhecer, desprendendo-se dos sentidos e do corpo; no Diálogo da alma e da ressurreição, a purificação é praticar a virtude, é purificar-se do pecado para assemelhar-se a Deus (ómoí $\omega \sigma \iota \varsigma \theta \varepsilon \hat{\omega})$ pela virtude.

Numa análise cristã deste fenômeno, pode-se-ia dizer que Platão defende a bem-aventurança da alma em um esquema que se aproxima das escatologias futuristas, enquanto que a proposta de Gregório é de uma escatologia inaugu$\operatorname{rada}^{21}$.

O uso dos sentidos como meio de apreensão da realidade é criticado em vários textos do Fédon (65 e - 66 b; 66 e - 67 a; 83 a-b; 99 e - 100 a). Esta influência de Platão foi acolhida por vários escritores cristãos, e também por Gregório. Este, contudo, "só toma esta posição num plano ético. Gnosiologicamente, a sua perspectiva é bem diversa, optando pela influência aristotélica. Para o bispo de Nissa, os sentidos constituem a base de todo o conhecimento e o intelecto depende deles" (Pacheco, 1983, p. 171-2). Neste aspecto Gregório se afasta de Platão.

Em outro ponto do Fédon, lemos a objeção de Cebes de que seria possível que a alma, ao sair do corpo, viesse a "dissipar-se como um sopro ou uma fumaça”. Este conceito que era compartilhado por alguns dos primeiros filósofos gregos (Fédon 70 a - 77 e), é também apresentado por Gregório, que inclusive faz alusão genérica a estes filósofos (De an. $17 \mathrm{a}-\mathrm{b})$.

Embora Sócrates não busque no Fédon alcançar uma definição detalhada de alma ( $\psi \cup \chi \eta ்)$, ela é afirmada como coisa de natureza simples (não composta), como tudo o que diz respeito ao inteligível, e ao divino (Fédon 78 e - 80 e).

Macrina, no Diálogo da alma e da ressurreição, apresenta logo no início da conversa, a pedido de Gregório, uma definição:

Alma é uma essência gerada, vivente e intelectual que transmite a um corpo orgânico e sensível, força vital e perceptiva das coisas sensíveis, através de sua própria natureza ${ }^{22}$.

A aproximação mais importante destas duas definições de alma está na relação dela com o Divino. Sócrates, tendo assentado a existência de duas espé- 
cies de seres, visíveis e invisíveis, faz Cebes admitir que a alma pertence à categoria das coisas invisíveis e o corpo à coisas visíveis. A alma, invisível, comanda o corpo, visível. Ele então apresenta o fato que a divindade invisível comanda os homens visíveis. A alma, portanto, em sua natureza e funções, tem afinidade (Fédon 79 d: $\sigma \cup \gamma \gamma \varepsilon v \hat{\alpha} \varsigma \varsigma$ o $\sigma \alpha$ ) com o divino, invisível. Eis uma razão de sua imortalidade e também a direção da alma, que uma vez separada do corpo, se encaminha para Deus (Fédon $80 \mathrm{~d}$ ).

Também esta noção platônica da afinidade da alma com o Divino é fundamental para Gregório de Nissa. Sua antropologia é governada por Gênesis 1.26 que afirma a criação do homem "à imagem e semelhança" de Deus ${ }^{23}$. A linguagem deste texto é adaptável ao pensamento platônico e ao mesmo tempo providencia autoridade bíblica para suas afirmações sobre a natureza e destino da alma ${ }^{24}$.

Assim, para Gregório, como semelhante atrai semelhante, a humanidade que carrega em si certas semelhanças ao seu Arquétipo (De an. 97 b: $\tau$ ô

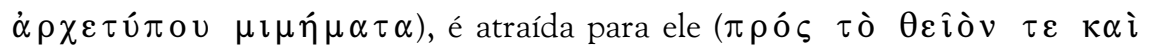
$\sigma \cup \gamma \gamma \varepsilon v \varepsilon \dot{\varepsilon} \dot{\eta} \psi v \chi \dot{\eta})$. A linguagem de suas declarações aproxima-se muito da utilizada no Fédon, e o argumento socrático é usado a serviço da teologia do nisseno. "Embora S. Gregório use a linguagem da filosofia platônica da participação, dá-lhe uma nota nitidamente cristã, ao acentuar o seu caráter gratuito e carismático" (Pacheco, 1983, p. 167).

Gregório define a própria natureza divina em termos oriundos da filosofia

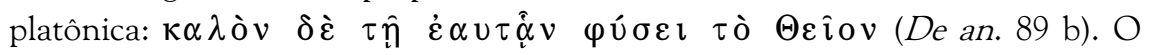

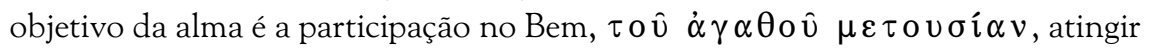

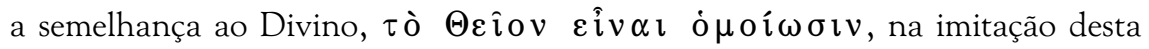

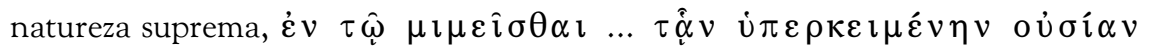
(De an. $89 \mathrm{~d}-92 \mathrm{a}$ ).

Outro detalhe do Fédon assumido e utilizado por Gregório de Nissa consta das observações de Sócrates sobre a etimologia da palavra Hades e sua conseqüente aplicação na filosofia.

Sócrates chama-o de "lugar invisível" (Fédon 80 d 5-6: $\tau$ ó $\pi$ ov $\underset{\alpha}{\alpha} \imath \delta \hat{\alpha} ; 81$ c 10-1). O pensamento contemporâneo a Platão, dizia que o nome aplicava-se bem ao deus que reinava sobre os mortos debaixo da terra, não sendo visível nem a homens nem aos deuses (Burnet, 1977, 80 d 6; Paleikat; Costa, 1983, p. 88, n. 1-2).

A mesma etimologia é assumida por Macrina, ao explicar que, o nome usado por escritores pagãos e cristãos se justifica. Todos afirmam que as almas 
dos homens vão para o Hades, depois da morte. Macrina explica que o Hades não é um lugar, mas o Mundo Invisível, usando explicação semelhante à encontrada no Fédon. A morte realiza a transição da alma do mundo visível para o

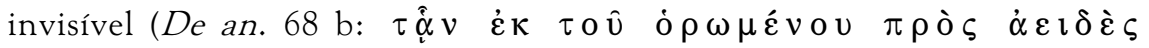

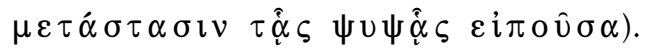

Um grande paralelo entre os dois diálogos pode ser traçado entre Fédon 81a-83e e o Diálogo da alma e da ressurreição 85 c - 97 d.

Sócrates afirma que a alma, antes de ser tomada aos cuidados da filosofia está acorrentada, colada (Fédon 82 e 2: $\delta \imath \alpha \delta \varepsilon \delta \varepsilon \mu \varepsilon \dot{\varepsilon} v \eta v \dot{\varepsilon} v \tau \hat{\omega} \sigma \omega \mu \alpha \tau \iota \kappa \alpha i$

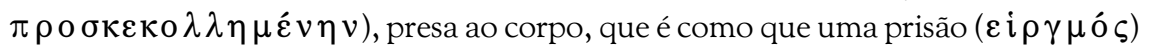
para ela. Desta forma, ela é mantida em ignorância, pois passa a encarar a realidade através do corpo e não por si mesma. O que torna esta prisão mais segura são os desejos. Destes o filósofo deve libertar-se e também dos sentidos para poder voltarse para si e examinar o que é inteligível e invisível (Fédon 82 d 9 - 83 c 2).

O prazer e a dor são apresentados como que tendo "uma espécie de cravo"

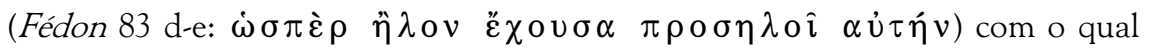
prendem a alma ao corpo, fazendo-a se conformar com o corpóreo $(\sigma \omega \mu \alpha \tau 0 \varepsilon \imath \delta \eta \zeta)$. Assim, esta alma não irá ao além purificada do corpo, mas logo irá buscar outro corpo e deixará de participar do que é divino, puro e único

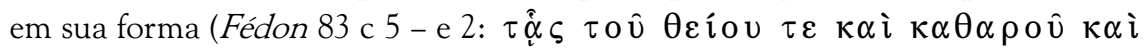

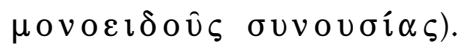

No Diálogo da alma e da ressurreição, depois de Macrina ter afirmado que a alma mantém relação com os elementos do corpo de modo a possibilitar a ressurreição, ela é desafiada por Gregório a harmonizar seus pontos de vista sobre a imortalidade da alma com a Parábola do Rico e de Lázaro ${ }^{25}$ que fala de almas no Hades.

Macrina explica que a parábola não deve ser tomada literalmente. Menciona elementos tais como o abismo, a gota de água conduzida por um dedo à uma língua, para mostrar que o texto convida a uma interpretação que não seja superficial. Ela então passa a apresentar sua explicação alegórica e platonizante da parábola. Segundo ela, a verdadeira interpretação da parábola só será possível "pela transposição de cada detalhe para o mundo das idéias" (De an. 80 c:

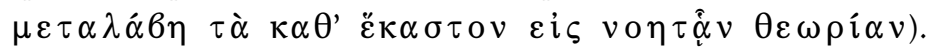

Neste ponto é importante notar que há um consciente e deliberado uso do recurso da filosofia platônica de seu tempo.

Ela afirma que a natureza humana é de caráter uno (De an. 81 b: $\mu \circ \operatorname{ov}_{\varepsilon} \delta \varepsilon \varsigma$ ), e totalmente voltado para o bem. A prática do mal gera uma 
mistura de contrários, prejudicial ao progresso da alma. O bem está ligado à mente e o mal ao sensíve (De an. $81 \mathrm{~d}$ ). Aquele que, como o rico, pratica o mal nesta vida sem a cura do arrependimento, gera um afastamento de sua alma do bem. Assim, o "abismo" relatado na parábola é resultado das decisões do homem que fica, ao morrer, privado do bem. O que pratica o bem vai para o lado de Abraão, que é conhecido como alguém que trocou os prazeres presentes pela esperança futura (De an. $84 \mathrm{a}-\mathrm{c}$ ).

Assim, o sofrimento pelo qual passa o rico, nada mais é do que uma "segunda morte", pela qual ele tem que passar para que sua alma seja libertada da "cola" que a mantém ligada à carne ( $\tau \hat{\alpha} \varsigma \sigma \alpha \rho \kappa \omega \dot{\delta}$ o $\varsigma \varsigma \kappa o ́ \lambda \lambda \eta \varsigma)$. Quando a alma for liberta desta prisão $(\delta \varepsilon \sigma \mu \hat{\omega} v \quad \tau \hat{\alpha} v \psi \psi \chi v \hat{\alpha} \hat{\alpha} v)$, poderá voar para o Bem, sem que nenhuma aflição do corpo $(\sigma \omega \mu \alpha \tau \iota \kappa \hat{\alpha} \varsigma \dot{\alpha} \lambda \gamma \eta \delta$ ó $\nu$ o $\varsigma)$ possa distraí-la (De an. 88 a). A conduta virtuosa é o meio de separar-se da carne de modo a não necessitar de uma segunda morte para livrar-se da cola que impede a alma livremente voe para o Bem. Conforme já observado anteriormente, estas idéias e até mesmo alguns termos fazem um exato paralelo com a exposição de Sócrates no Fédon.

Macrina continua dizendo que para os amantes da carne ( $\varphi \imath \lambda$ ó $\sigma \alpha \rho \kappa o \varsigma)$ há dificuldade de ascender para o Bem, mas ficam rondando as tumbas, "como

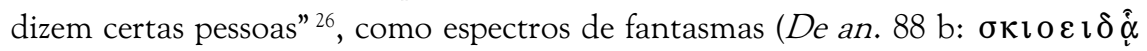
$\varphi \alpha \nu \tau \alpha ́ \alpha \mu \alpha \tau \alpha)$. Estes, estão como que transfixados pelos cravos da propensão

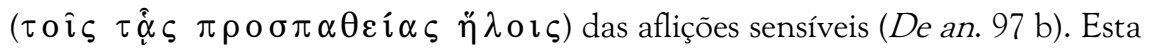
menção de cravos demonstra novamente a dependência de Gregório em relação ao Fédon.

No Fédon, Sócrates já havia falado da purificação como separar o mais

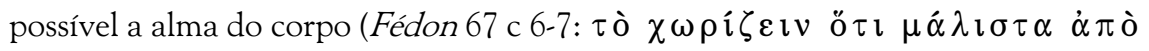

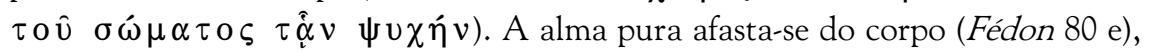
enquanto que a impura tem qualidades corpóreas (Fédon 81 c), e acaba entrando de novo em um corpo (Fédon 81 e).

A expressão de Macrina $\sigma \kappa \imath$ c $\imath \delta \hat{\alpha} \quad \varphi \alpha \nu \tau \hat{\alpha} \sigma \mu \alpha \tau \alpha$, originou-se no Fédon sendo uma citação literal do mesmo (Fédon 81 d). Esta aproximação a entre as duas obras revelam a dependência de Gregório sobre o Fédon até mesmo a nível de vocabulário e metáforas.

Há contudo que se notar contrastes. Conforme se observa "existe uma grande diferença entre o tratamento do tópico por Gregório e o de Platão” (Roth, 1992, p. 22). Platão fala consistentemente da purificação da alma e de sua liber- 
tação do corpo $(\sigma \hat{\omega} \mu \alpha)$. Gregório, por outro lado, e de acordo com a tradição bíblica, fala, preferencialmente ${ }^{27}$, de libertação da carne $(\sigma \dot{\alpha} \rho \xi)$. A diferença é ocasionada pela crença cristã que o corpo é bom, enquanto criação divina ${ }^{28}$. A distinção entre corpo $(\sigma \hat{\omega} \mu \alpha)$ e carne $(\sigma \hat{\alpha} \rho \xi)$ é típica da teologia do apóstolo Paulo. Percebe-se, portanto, que Gregório trabalha interagindo com duas linguagens: a bíblica e a filosófica, harmonizando-as para atingir seus objetivos. Como diz Roth:

Assim, o tema platônico da purificação da alma (ele mesmo introduzido por uma parábola bíblica) veio a ser modificado pela distinção paulina entre corpo e carne. Este tipo de entretecimento de temas platônicos e bíblicos é típico do método de Gregório neste diálogo (Roth, 1992, p. 23).

A objeção de Símias, apresentando a alma como uma harmonia dos elementos que se desfaria com a morte, ocasionando também a destruição da alma (Fédon 85 e - 86 e), também é aproveitada no diálogo de Gregório com sua irmã (De an. 20 b - 21 a). Gregório objeta que a alma pode bem ser uma coisa complexa, e portanto, ao se separar nas partes constituintes, haveria a destruição da alma.

Macrina refuta esta objeção por um argumento ab absurdo, mostrando que tal modo de pensar nega a própria Divindade (De an. 21 a - 28 a).

Como era de se esperar, na resposta desta objeção, há um distanciamento entre Platão e Gregório. Platão usará o argumento da reminiscência logo no começo de sua argumentação (Fédon 92 c), em seguida, contudo, também reduzirá a um absurdo a afirmação de ser a alma uma harmonia (Fédon 93 a - 95 a).

Em certo ponto do Fédon, Sócrates fala das almas assumindo, em sua $\pi \alpha \lambda \imath \gamma \gamma \varepsilon v \varepsilon \sigma i \alpha$, características daquilo que mais ansiavam em sua vida anterior. Tornam-se animais de várias classes. Libertam-se deste rebaixamento os que optaram pela filosofia (Fédon 81 e - 82 c).

A $\pi \alpha \lambda \imath \gamma \gamma \varepsilon v \varepsilon \sigma i \alpha$ (tardiamente chamada $\mu \varepsilon \tau \varepsilon \mu \psi \dot{v} \chi \omega \sigma \imath \varsigma)$ mencionada por Platão não pode ser assumida por Gregório, mas mesmo negando tal possibilidade rotulando-a de absurda, ela é incorporada no diálogo de Gregório como um argumento a favor da ressurreição. Macrina diz que já que os pagãos aceitam a possibilidade de transmigração das almas, isto não se afasta demais do conceito de ressurreição (De an. 108 b-c). Duas alusões quase diretas aos casos expostos por Sócrates são feitas por Macrina (De an. 112 d - 113 a; 116 b). 
Mesmo negando as doutrinas platônicas sobre o destino das almas, Gregório assinala neste pensamento o que ele tem de comum (ou de utilitário) com a doutrina cristã da ressurreição: "que a alma dos que partiram pode assumir outro corpo" (Moore; Wilson, 1892, p. 456, n. 7).

Sócrates, em certo ponto do diálogo, usa mão dum argumento moral contra os filósofos materialistas (Fédon 98 e 1 - 99 b 2). Ele afirma, contra Anaxágoras, que se tudo se resumisse ao material, não haveria motivo para que ele mesmo não tivesse fugido para Mégara ou outro lugar. Sua opção pelo justo e pelo belo são a verdadeira causa de sua ação moralmente significante.

É também com um argumento moral que Macrina inicia seu discurso contra as concepções que negavam sobrevivência à alma (De an. 17 b-c). Sem a sobrevivência da alma, não há valor nem sentido para a virtude.

\section{O Sagrado e a Filosofia: um caso de apropriação reversa}

O Fédon, como um diálogo sobre a imortalidade da alma, inevitavelmente chama a atenção para os interesses e aspectos religiosos vinculados ao tema. Hegel, contudo nos adverte:

A imortalidade não tem, em Platão, o interesse que tem para nós a partir de um ponto de vista religioso; ... nele se acha relacionada com a natureza do pensamento, com a liberdade interior do mesmo, guarda também relação com a determinação que constitui o fundamento do excelente da filosofia platônica, com o terreno do supra-sensível estabelecido por Platão (Hegel, 1955, p. 167).

Segundo Hegel, a intenção de Platão, no diálogo é "demonstrar, mediante a tese da reminiscência, que o espírito, a alma, o pensamento são livres em si e para si; e isto, entre os antigos e principalmente na representação platônica, guarda uma relação direta com o que nós chamamos de imortalidade da alma" (id. ib. p. 166).

Tomando como ponto de partida estas palavras de Hegel, observa-se que o alvo de Platão é utilizar a questão da imortalidade da alma para fazer filosofia. Seu objetivo último não é religioso embora sua temática e linguagem possam assim nos parecer. 
O que temos no Fédon é o uso de conceitos e da linguagem mítico-religiosa de seu tempo, a serviço da filosofia. Como diz Andrade:

No Fédon, ao resgatar da tradição algumas afirmações que tem suas significações específicas dentro de um sistema mítico-religioso e de uma linguagem inaugurada pelos primeiros físicos, ele as transfere para o campo metafísico, onde a importância da imortalidade, por exemplo, relaciona-se tão somente ao conhecimento da verdade e ao exercício reflexivo; mais ainda, transmuta a crença na pureza da alma e impureza do corpo para a perspectiva gnoseológica (do sensível $=$ impuro ao inteligível $=$ puro $)($ Andrade, 1993, p. 29).

Pode-se preceber alguns aspectos do Fédon nos quais Platão está se apropriando da linguagem religiosa e mítica tradicional em direção à formação de uma religiosidade filosófica. Os termos e temas utilizados por Platão vêm do ambiente da religião e do culto, mas ele os molda e redefine-os para seus propósitos de expor filosofia.

O primeiro elemento a ser notado é a "moldura" do diálogo. O elemento religioso emoldura o diálogo. Ele começa com a menção da peregrinação a Delos em honra de Apolo e termina com a recomendação de oferta de um galo a Asclépio. O registro desta ambientação não é casual, mas intencional, visando utilizar os elementos do culto, transformando-os em favor da filosofia.

O prólogo do diálogo apresenta a razão da demora da execução de Sócrates, ao mesmo tempo que introduz dois importantes temas religiosos do diálogo que serão utilizados no discurso filosófico de Sócrates: (1) o serviço dos homens aos deuses e (2) a purificação. O próprio Sócrates se apresentará como servo de Apolo (Fédon 60 d 2; 61 b 2-3; 85 b 4-5) e a purificação será um tema dominante do diálogo (Gallop, 1975, p. 75).

A menção de Apolo, divindade ligada ao conhecimento contemplativo (Otto, 1976, p. 64), à pureza, à cura (id. ib. p. 54-5) e à morte maravilhosa (id. ib. p. 61), desde o início da obra, é um preparo para a exposição da filosofia à partir dos termos da religiosidade grega.

A devoção de Sócrates a Apolo era levada a cabo pela filosofia ( Fédon 85 b 4-6) e sua morte ocorrerá de modo tão sereno (Fédon 58 e; 117 - 118) como se ele, ao invés de tomar veneno, tivesse sido atingido por uma das "flechas suaves" de Apolo (Otto, 1978, p. 119). 
Assim, filosofia e religiosidade se sobrepõem mostrando "a enorme diferença entre a religiosidade grega e a moderna ... O filósofo (Sócrates) pode conceber sua busca rigorosa da verdade como o encargo sagrado da divindade (Apolo)" (Otto, 1978, p. 117). É justamente esta reinterpretação do culto na forma de filosofia que caracteriza a obra de Platão como promotora de uma religiosidade filosófica.

O uso da idéia de "purificação" no Fédon é um dos momentos onde mais claramente se pode observar a utilização filosófica de um termo associado à religião. Tal utilização, como se observará, não se faz por puro empréstimo do termo ou por sua utilização em uma analogia, mas por uma reinterpretação de seu sentido, tornando-o pertinente à filosofia.

Os termos traduzidos por purificação são: $\kappa \alpha \dot{\alpha} \theta \alpha \rho \sigma \iota \varsigma$ (Fédon 67 c 5; 69 c 1) e $\kappa \alpha \theta \alpha \rho \mu$ ó $\varsigma$ (Fédon 69 c 2). "К $\alpha \theta \alpha \rho \sigma \iota \varsigma$, palavra com implicações religiosas e médicas. ... Entre os pitagóricos a $\kappa \alpha \dot{\alpha} \theta \alpha \rho \sigma \iota \varsigma$ tinha, como era de se esperar, fortes conotações religiosas" (Peters, 1983, p. 121). Pitagóricos usavam a idéia de modo singular, associando a ela não apenas aspetos filosóficos mas também práticas ascéticas (Burnet, 1977, 67 c 5). O Fédon, como se observa pelos personagens apresentados, é um diálogo "dedicado, por assim dizer, à comunidade pitagórica de Fliunte” (id., 1994, p. 77, n. 3).

Por outro lado, é importante lembrar que "purificação" era um termo religioso amplamente utilizado e que de modo algum estava restrito ao pitagorismo. " $\kappa \alpha \theta \alpha \rho \mu$ ó $\varsigma$... é um termo religioso específico para a cerimônia iniciatória de purgação" (id., 1977, 69 c 2), e portanto, aplica-se a vários cultos e rituais da antigüidade. O termo $\kappa \alpha ́ \theta \alpha \rho \sigma \iota \varsigma$ também é uma "idéia central do orfismo" (id. ib. 69 c 2). A frase de Sócrates, "ao impuro, do puro apossar nunca jamais lícito seja” (Fédon 67 b 2), era, sem dúvida, um axioma do mundo grego, no que diz respeito ao culto.

Friedrich Hauck (Hauck, 1965, p. 415-6) observa que a purificação cúltual poderia ser realizada para: (1) aproximar-se da divindade, seja para aproximar-se do santuário ${ }^{29}$, seja em sacrifícios (Hes. TD 336-7); (2) remover algum miasma ou impureza em que se incorreu. Mas, juntamente com a purificação religiosa, desenvolveu-se aquele tipo de purificação do corpo praticada pelo asceticismo e pelas iniciações (Ferguson, 1987, p. 123-4). No orfismo (id. ib. p. 124) e no pitagorismo (Burnet, 1994, p. 77; Kirk, Raven, Schofield, 1994, p. 231), as purificações ajudariam a escapar do ciclo dos renascimentos ${ }^{30}$.

No Fédon, a purificação é apresentada como um afastamento da alma em relação ao corpo: 
E o mesmo acontece a quem quer que possa afirmar que seu pensamento está pronto e o possa dizer purificado. ... Mas, a purificação não é, de fato, justamente o que diz uma antiga tradição? Não é apartar o mais possível a alma do corpo (Fédon 67 c).

Tais declarações mostram como o conceito de purificação, aplicado a rituais religiosos ou a práticas ascéticas, vai ser reinterpretado para significar purificação pela filosofia. O afastamento maior da alma do corpo, como se observará, é a morte do filósofo.

\section{Como diz Sócrates:}

Talvez ... a (virtude) verdadeira nada mais seja do que uma certa purificação de todas essas paixões (mencionadas anteriormente) e seja a temperança, a justiça, a coragem; e o próprio pensamento outra coisa não seja do que um meio de purificação. É possível que aqueles mesmos a quem devemos a instituição das iniciações não deixem de ter o seu mérito, e que a verdade já de há muito tempo se encontre oculta sob aquela linguagem misteriosa. Todo aquele que atinja o Hades como profano e sem ter sido iniciado terá como lugar de destinação o Lodaçal, enquanto aquele que houver sido purificado e iniciado morará, uma vez lá chegado, com os Deuses. É que, como vês, segundo a expressão dos iniciados nos mistérios: numerosos são os portadores de tirso, mas poucos os Bacantes. Ora, ao meu ver, estes últimos não são outros senão os de quem a filosofia, no sentido correto do termo, constitui a ocupação (Fédon 69 b $8-\mathrm{d} 2)$.

Nota-se neste texto a transposição da linguagem e dos conceitos do mito e do culto para a filosofia: (1) a filosofia e o pensamento são os verdadeiros meios de purificação; (2) o filósofo é o verdadeiro iniciado. Reale afirma: "Eis uma passagem significativa do Fédon (69 a-d) na qual a virtude, saber e purificação são identificados e a filosofia coincide com a verdadeira iniciação dos mistérios" (Reale, 1994, p. 214). Em nosso ponto de vista, modificaríamos a observação de Reale para dizer que a filosofia não coincide com as iniciações dos mistérios, mas que a filosofia é a verdadeira iniciação e purificação, prefigurada religiosamente nos mistérios. Sócrates dirá que os verdadeiros iniciados "não são outros senão os de quem a filosofia, no sentido correto do termo, constitui a ocupação" (Fédon 69 d 1-2). Em sua exposição do sentido da filosofia, ele lança mão do vocabulário e 
dos rituais religiosos, mas aplica-os ao filosofar, defendendo esta última como a verdadeira e mais elevada religiosidade.

Quando fala jocosamente do destino futuro das almas não purificadas, ou seja, das que não se "afastaram do corpo", ele as apresenta voltando a corpos divididos em três categorias, conforme suas características reveladas em vida. Os incontinentes entrarão em corpos de animais brutos e vorazes; os dedicados à rapina, tornar-se-ão animais deste tipo; os que vivem nas normas da pólis voltarão em seres gregários ou em forma humana (Fédon 81 e - 82 c). Mas a quarta categoria não voltará a um corpo mas passará a viver em companhia dos deuses (Fédon 81 a):

Quanto à espécie divina, absolutamente ninguém, se não filosofou, se daqui partiu sem estar totalmente purificado, ninguém tem o direito de atingí-la, a não ser unicamente aquele que é amigo do saber (Fédon 82 b).

Este afastamento do corpo, através da filosofia, realiza-se pelo abster-se dos sentidos. A filosofia liberta o homem dos grilhões do corpo, que é uma prisão,

mostrando-lhes para isto de quantas ilusões está inçado o estudo que é feito por intermédio dos olhos, tanto como o que se faz pelo ouvido e pelos outros sentidos; ... recomendo-lhes que se concentrem e se voltem para si, não confiando em nada mais do que em si mesmas (Fédon 83 a).

Como diz Reale:

Esta purificação se realiza quando a alma, transcendendo aos sentidos, toma posse do mundo do inteligível puro e do espiritual, unindo-se a ele como ao que lhe é congênito e conatural. A purificação aqui, diversamente das cerimônias iniciáticas dos órficos, coincide com o processo de elevação ao conhecimento supremo do inteligível. É necessário refletir justamente sobre esse valor da purificação reconhecido à ciência e ao conhecimento, para compreender a novidade do "misticismo" platônico: ele não é uma contemplação alógica e extática, mas um esforço catártico de pesquisa e de subida progressiva ao conhecimento. Assim se entende perfeitamente por que o processo do conhecimento racional seja, para Platão, processo de 
conversão moral: na medida em que o processo do conhecimento conduz-nos do sensível ao supra-sensível, converte-nos de um mundo a outro e nos leva da falsa à verdadeira dimensão do ser. Portanto, conhecendo, a alma se cura, purifica-se, converte-se e se eleva. Nisso consiste sua virtude (Reale, 1994, p. 214).

No abandono do sensível e na busca do inteligível, a alma se purifica. A linguagem religiosa de purificação é redefinida em termos da filosofia platônica e nela atinge, ao ver do filósofo, sua verdadeira realização.

É por isto que a morte é, de fato, a culminação da purificação do filósofo. A definição de morte que o texto nos apresenta é: "a separação da alma do corpo" ${ }^{31}$. Mas como observou-se anteriormente, é justamente a separação dos desejos do corpo e dos sentidos que o filósofo busca para realizar sua purificação. Logo, a morte é, para o filósofo, a purificação maior.

Sócrates argumenta:

Se com efeito, é impossível, enquanto perdura a união com o corpo, obter qualquer conhecimento puro, então de duas uma: ou jamais nos será possível conseguir de nenhum modo a sabedoria, ou a conseguiremos apenas quando estivermos mortos, porque nesse momento a alma, separada do corpo, existirá em si e por si mesma (Fédon 66 e).

Desta forma, a observação inicial de que o filósofo é o tipo de homem para quem a "única preocupação consiste em preparar-se para morrer e estar morto" (Fédon 64 a), fica completamente justificada.

É irônico, portanto, que o cuidado de Atenas em não contaminar-se com uma execução durante a peregrinação a Delos, atrapalhasse a completa purificação de Sócrates, na sua morte (Gallop, 1988, p. 75).

Sobre esta transposição da purificação religiosa para a filosofia, R. E. Doods comentou:

Quando Platão se apossou da noção mágico-religiosa da PSYCHE, apossou-se em primeiro lugar do dualismo puritano, que atribuía todos os pecados e sofrimentos da PSYCHE à poluição, que surge do contato com o corpo mortal. No Fédon, transpôs esta doutrina para termos filosóficos e deu-lhe a formulação que se tornaria clás- 
sica: só quando, pela morte ou pela autodisciplina, o Eu racional é purgado da 'loucura do corpo' pode recuperar sua verdadeira natureza, que é divina e sem pecado; a boa vida é a pratica desta purificação, MELETE THANATOU (Dodds, 1988, p. 229).

Assim, no Fédon, temos a redefinição de purificação cultual e religiosa em termos da filosofia.

Quando falamos de purificação, o alvo do purificado é o contato com os deuses. Mas também nesta área, Platão apresenta uma nova transposição de elementos do mundo religioso para o campo da filosofia. Ele aproxima o divino e as Idéias, de forma que o alvo da filosofia e de sua purificação é conduzir-nos ao que é verdadeiro, ao inteligível, às divinas idéias.

Em certo momento do diálogo ele afirma: "Admitamos, portanto, que há duas espécies de seres: uma visível e outra invisível” (Fédon 79 a). Sem dúvida ele fala aqui do sensível e do inteligível, sendo que estas são as únicas classificações possíveis para os seres.

Posteriormente, ele irá aproximar o divino à alma e o mortal ao corpo:

Quando estão juntos a alma e o corpo, a este a natureza consigna servidão e à primeira comando e senhorio. Sob este novo aspecto, qual dos dois se assemelha ao que é divino e qual ao que é mortal? ... - Nada mais claro, Sócrates! A alma com o divino; o corpo, com o mortal (Fédon 106 d-e).

Assim, sendo a alma similar ao divino e o corpo ao mortal, mas havendo apenas duas espécies de seres, os sensíveis e os inteligíveis, logicamente, a alma, o divino e o inteligível constituem uma espécie de seres que se contrastam com o corpo, o mortal e o sensível. Tal aproximação fica evidente em seu raciocínio que diz:

Todos estão de acordo em que Deus e a própria idéia de vida, e o mais que de imortal existe, nunca desaparecem? ... Por conseguinte, o que é imortal é também indestrutível; e a alma sendo imortal não deve ser também indestrutível? - Necessariamente! (Fédon 106 d-e).

Seu objetivo, neste texto, é do de concluir sua argumentação em prol da tese da imortalidade da alma. O que é declarado de passagem é a clara aproxima- 
ção das Idéias com o divino, e assim, Platão realiza mais uma apropriação de conceitos religiosos e os utiliza na filosofia, desta vez, aproximando o divino das Idéias.

Portanto, a purificação da alma para os filósofos, é na verdade, abstrair-se dos elementos sensíveis e apropriar-se do inteligível. Tal processo culmina na morte, onde ele deixa o mundo sensível para estar em contato com os Deuses (Fédon 63 b), e na verdade, ter o perfeito conhecimento das Idéias (Fédon 66 e - 67 a).

Num diálogo onde os elementos religiosos foram constantemente transpostos para a prática da filosofia, o epílogo funciona como uma espécie de coroação, não apenas da tese principal do diálogo, a imortalidade da alma, mas também da metodologia de reinterpretação do mito e do culto como filosofia.

Já no leito de morte, mas ainda com sua jocosidade habitual, Sócrates diz: "Críton, devemos um galo a Asclépio; não te esqueças de pagar esta dívida" (Fédon 118 a 7-8). "Sócrates espera levantar curado como aqueles que eram curados por

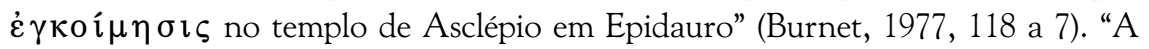
Asclépio, deus da medicina, era costume oferecer-se um galo, quando alguém curava de uma doença. Mas aqui as palavras de Sócrates, segundo alguns, são simbólicas: a sua morte é a convalescença da doença da vida" (Platão, 1975, p. 112).

Sócrates, assim, usa a linguagem do mito e do culto (religiosa) a serviço da transmissão da idéias filosóficas. Tal atitude é o que se faz em toda a obra. $\mathrm{O}$ sacrifício a Asclépio é a definitiva utilização do culto como parábola à serviço da filosofia. Este último evento do diálogo apresenta, de fato, um paradigma que se repete na obra toda.

Nos exemplos citados observa-se um comportamento deliberado no Fédon: Platão lança mão de conceitos e da linguagem mítico-religiosa a serviço da filosofia, acabando por deixar entrever uma religiosidade filosófica.

A preocupação da obra não é tanto religiosa nem escatológica, no que diz respeito ao destino das almas, mas filosófica, no sentido ficar patente a superioridade do inteligível sobre o sensível. A filosofia é o meio de apropriar-se do inteligível, do divino, do puro, do imortal e de tudo que tem verdadeiro valor.

\section{O Diálogo da alma e da ressurreição e a Filosofia}

O que faz Gregório de Nissa em sua obra é justamente o reverso do que fez Platão: ele apropria-se da linguagem filosófica de seu tempo para utilizá-la como veículo de exposição de sua teologia cristã. 
Sem dúvida, a filosofia grega contemporânea a Gregório era predominantemente religiosa. As preocupações éticas e religiosas são marcantes, e o que se nota nas escolas do período era um interesse geral por compilar, comentar e preservar as obras e pensamentos das épocas anteriores (Pacheco, 1983, p. 20-4). $\mathrm{O}$ que ocorreu no cristianismo do período (séculos IV e V), foi justamente o contrário: havia um clima de euforia do triunfo e o florescimento de uma cultura própria alicerçada na cultura clássica. A filosofia pagã se estagnava e a cristã florescia (id. ib. p. 24, n. 20).

Gregório é um dos melhores representantes do espírito filosófico cristão de seu tempo. Como diz Stein:

Ele não seguia nenhuma escola específica, mas usava o senso comum e seu julgamento para selecionar idéias dos vários sistemas, considerando que a filosofia pagã era apenas uma meio para chegar a um fim [religioso] (in: Cherniss, 1971, p. 1).

Clemente de Alexandria (Séc. II), primeiro cristão filósofo, e Orígenes (Séc. III) tentaram apresentar o cristianismo como um sistema filosófico, mas foi Gregório de Nissa que, efetivamente, conseguiu submeter a filosofia a serviço da teologia (Cherniss, 1971, p. 1). Há quem chegue a considerá-lo o maior teólogofilósofo dentre todos os escritores cristãos do século IV (Malherbe, Ferguson, 1978, p. 143, n. 17).

A purificação da alma, para Gregório, ocorre tanto nesta vida como na próxima. Esta purificação é feita tanto pelo esforço contínuo e disciplinado de praticar a virtude nesta vida, como pela purgação após a morte das almas contaminadas pelo pecado desta vida. Seu aspecto positivo é a busca de uma vida perfeita baseada na $\theta \varepsilon \omega \rho i ́ \alpha$ ou contemplação de Deus, visando uma união aperfeiçoada com ele. $\mathrm{O}$ aspecto negativo é caracterizado pela dolosa purgação das almas após a morte, de suas contaminações com o pecado desta vida (De an. 88 a).

Estes dois aspectos incentivam e justificam a prática da virtude como meio de aproximação da divindade (De an. 88 a; 89 b). Por outro lado, Deus é a fonte de toda a virtude (De an. 104 a), de modo que a prática desta é originária nele e se destina a ele. Numa generalização, na filosofia platônica, o fim não é a moralidade (que no sentido cristão só poderia ser aplicado aos gregos anacronicamente), mas o conhecimento, que por sua vez, implica moralidade. Já na filosofia patrística, o fim de todo trabalho filosófico, mesmo aquele que escla- 
rece o dogma, é o comportamento, a vida prática. Aquela preocupa-se em conhecer e essa em praticar.

Esta prática da virtude irá caminhar na direção de fortalecer o ideal monástico, recém organizado na Ásia Menor por sua família, embora não se restrinja a ele (Jaeger, 1991, p. 115-6). Como diz Jaeger:

Foi Gregório de Nissa quem transferiu as idéias da paideia grega na sua forma platônica para a vida do movimento ascético que se originou na Ásia Menor e no Oriente Próximo, e que em breve viria dar mostras de um poder de atração não sonhado. Da sua Capadócia natal e do Ponto, estas idéias espalharam-se à Síria e à Mesopotâmia, onde foram, mais tarde, retomadas pelos místicos islâmicos, vindo igualmente, a alastrar até aos Ocidente de língua latina (id. ib. p. 125).

Mesmo o sofrimento após a morte dos que não se purificaram nesta vida no caminho da virtude é visto, não como um ato de vingança divina, mas de amor, como meio de purgação necessária para que a alma impura consiga atingir o bem da comunhão com o Divino (De an. 97 b - 100 b). Neste aspecto, Gregório, seguindo a influência de Orígenes, deixou-se influenciar pelas conseqüências deste pensamento, ao ponto de negar a doutrina bíblica do castigo eterno. Para ele, na restauração final de todas as coisas, não há lugar para o Inferno (De an. 160 b-c). Como diz Jaeger:

Como símbolo da catarse paidêutica da alma e da sua alienação do mal, Gregório aceita o mito de Platão e o dogma cristão do castigo na outra vida; mas não aceita a idéia cristã de um castigo eterno depois da morte (Jaeger, 1991, p. 114).

Se Platão, usando a linguagem religiosa definiu a filosofia como buscar assimilar o Divino, Gregório volta tal expressão ao seu sentido religioso, implementandoa com o conceito bíblico da criação do homem à imagem de Deus. Para Gregório, a verdadeira filosofia era a prática da religião cristã, onde a semelhança com Deus é obtida através de Jesus, o Filho de Deus e homem perfeito.

A utilização das categorias platônicas do sensível e do inteligível ligadas à gnoseologia é outro exemplo da apropriação da filosofia para fins religiosos. Gregório assume estas categorias para construir sua cosmologia e sua defesa da 
existência da alma (De an. 28 c). Como cristão, ele é necessariamente monista, acreditando que o mundo material é criação divina, sendo portanto o sistema Criador-criatura predominante sobre o esquema sensível-inteligível, o qual ele utiliza e redefine (Pacheco, 1983, p. 120).

Gregório define Deus como "o arquétipo do Bem", e a natureza divina é identificada com o Bem. Tal uso das categorias filosóficas platônicas para explicitar a religião cristã pervade todo o pensamento deste que usa a filosofia em prol do dogma.

As palavras de Jaeger definem bem o processo de apropriação da filosofia pela religião:

Esta forma de utilizar as categorias básicas da filosofia grega como uma armação a ser preenchida com o conteúdo cristão assemelhase aos esforços de Gregório [de Nissa] noutros campos, como por exemplo, quando edifica sua própria cosmologia ou sistema de ética cristãos em contrapartida às formas correspondentes da tradição grega (Jaeger, 1991, p. 124).

\section{Apropriação reversa}

O que chamamos de apropriação reversa é justamente o uso de conceitos e termos do mundo religioso e do mundo filosófico em diferentes direções, quando comparamos o Fédon e o Diálogo da alma e da ressurreição. No Fédon, Platão se apropria da linguagem e conceitos religiosos de seu tempo e os utiliza na formação e transmissão da sua filosofia. No Diálogo da alma e da ressurreição vemos Gregório apropriando-se da linguagem, dos conceitos e da própria filosofia platônica (entre outras) no seu propósito de explicitar a fé cristã.

\section{Notas}

* Mestre em Grego pelo Programa de Pós-Graduação em Letras Clássicas da FFLCHUSP e Professor do Seminário Bíblico Nacional.

1 Apologista cristão, cerca de 165 d.C..

2 Bispo cristão em Olimpo, na Lícia, cerca de 311 d.C., escreveu "O Banquete", um diálogo calcado na obra homônima de Platão no qual dez moças celebram sua decisão pelo celibato (Norris, 1990, p. 595; Brown, 1990, p. 160-1). 
3 Numênio, filósofo neopitagórico de Apamea (Síria) que viveu no fim do segundo século d.C.

4 Clemente de Alexandria, Strom. 1.22; Eusébio de Cesaréia, Praep. Evang. 9.7-8 : $\tau$ ì $\gamma \dot{\alpha} \rho \dot{\varepsilon} \sigma \tau \imath \Pi \lambda \dot{\alpha} \tau \omega \nu$ ฑิ $\mathrm{M} \omega \nu \sigma \hat{\alpha} \zeta \dot{\alpha} \tau \tau \imath \kappa i \zeta \omega \nu ;$.

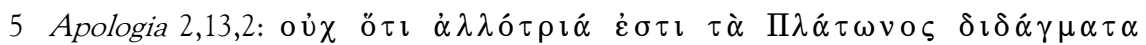

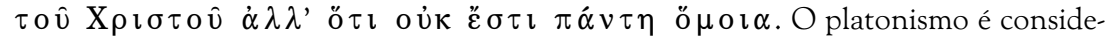
rado como preparatório para a revelação cristã.

6 Basílio, o Grande, bispo de Cesaréia.

7 Macrina, a jovem, em distinção à sua avó homônima, que foi discípula de Gregório Taumaturgo, bispo de Neocesaréia.

8 Os Três Grandes Capadócios ou os "Pais" Capadócios são: Basílio, o Grande, Gregório de Nazianzo e Gregório de Nissa.

9 Basílio e Gregório de Nazianzo estudaram em Atenas numa época de "reavivamento" dos estudos filosóficos e retóricos clássicos, que culminou nos tempos de Juliano, o apóstata.

10 Renascimento do Platonismo dos séculos I e II d.C., onde certos elementos dos ensinos de Platão são selecionados e sistematizados (Pacheco, 1983, p. 50).

11 "Neoplatonismo difere do Platonismo em sua nova combinação das teorias contraditórias anteriores e na sua orientação profundamente religiosa" (Berchman, 1990, p. 641).

12 Estoicismo, Aristotelismo, Cinismo.

$13 \Pi \varepsilon \rho \grave{\imath} \psi v \chi \underset{\alpha}{\alpha} \varsigma \kappa \alpha i ̀ ~ \dot{\alpha} v \alpha \sigma \tau \alpha \sigma \varepsilon \omega \varsigma$ ò $\lambda o ́ \gamma$ o $\varsigma$, ou De anima et resurrectione dialogus. Neste trabalho doravante designado nas notas como De Anima.

14 "É indubitavelmente verdadeiro dizer que Gregório queria indicar que o diálogo deveria ser lido como uma espécie de Fédon Cristão" (Roth, 1992, p. 21). "O Diálogo da alma e da ressurreição espelha o Fédon de Platão" (Denning-Bolle, 1989, p. 98). "Quanto ao Fédon, é inegável que está na base de Dialogus de anima et resurrectione, pois as circunstâncias e os temas tratados são muito semelhantes" (Pacheco, 1983, p. 51). “A igreja deveria possuir o seu Fédon, ou Diálogo de Leito de Morte, e Gregório a supriu disto com seu Diálogo da alma e da ressurreição" (Moore, Wilson, 1892, p. ix).

15 Sobre o conceito de Gregório da Bíblia como paideia, ver Jaeger, 1991, p. 117-9.

16 Traducianismo: uma das quatro teorias da origem da alma do indivíduo, isto é, que diz que a alma, assim como o corpo, vem dos pais (Wright, 1990, p. 569).

17 Restauração final ou Apocatástase: doutrina da salvação universal. Segundo ela, todos, até os demônios chegarão a Deus e serão restaurtados à sua condição original (Demarest, 1990, p. 62-63).

18 Giovanni Reale (Reale, 1994, p. 22, 27, 29) afirma que a não sistematicidade dos diálogos platônicos é atribuída ao desejo deliberado de manter a dimensão da oralidade da filosofia, deixando os escritos apenas como recurso à memória de quem já sabe o fundamental, isto é, as "Doutrinas não-escritas". 
19 Talvez bem a propósito do comportamento diante de Macrina em seu leito de morte em um Mosteiro. O ambiente, contudo, fica carregado.

20 Giovanni Reale (id. ib. p. 185-6) insiste que as provas são três: 1. Originação nos contrários e a reminiscência; 2. Afinidade com as idéias: logo, eterna. 3. Natureza das idéias: exclusão do contrário.

21 Escatologia Futurista é aquela em que os conceitos e esperanças propostos se cumprem apenas no futuro em contraste com a Escatologia Inaugurada na qual as bênçãos do porvir invadem o presente.

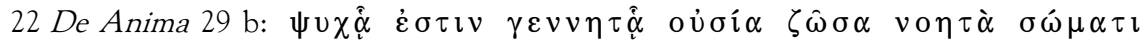

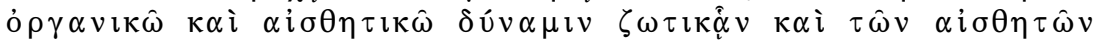

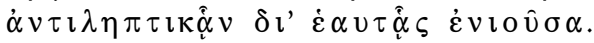

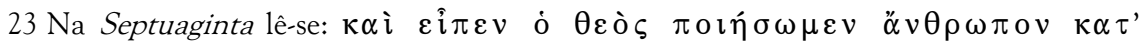

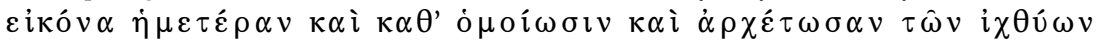

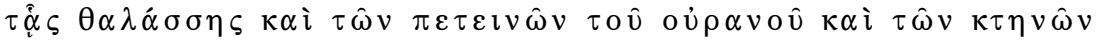

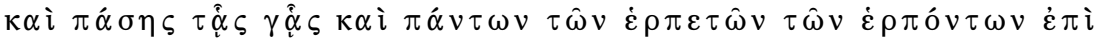
$\tau \stackrel{\alpha}{\varsigma} \zeta \gamma \hat{\alpha} \zeta$. "Desde o início da teologia cristã e durante todo o período patrístico, este versículo 26 do capítulo I do Gênesis foi largamente comentado, estimulando uma nova antropologia. O tema do homem-à-imagem será, ao longo dos tempos, um dos mais ricos e complexos do pensamento ocidental, originando uma larga tradição filosófica e mística" (Pacheco, 1983, p. 163-4).

24 De Anima 41 c, onde o texto mosaico é interpretado pelas categorias do pensamento platônico.

25 Evangelho de Lucas 16.19-31: 19 Ora, havia um homem rico que se vestia de púrpura e de linho finíssimo, e todos os dias se regalava esplendidamente. 20 Ao seu portão fora deitado um mendigo, chamado Lázaro, todo coberto de úlceras; 21 o qual desejava alimentar-se com as migalhas que caíam da mesa do rico; e os próprios cães vinham lamber-lhe as úlceras. 22 Veio a morrer o mendigo, e foi levado pelos anjos para o seio de Abraão; morreu também o rico, e foi sepultado. 23 No Hades, ergueu os olhos, estando em tormentos, e viu ao longe a Abraão, e a Lázaro no seu seio. 24 E, clamando, disse: Pai Abraão, tem misericórdia de mim, e envia-me Lázaro, para que molhe na água a ponta do dedo e me refresque a língua, porque estou atormentado nesta chama. 25 Disse, porém, Abraão: Filho, lembra-te de que em tua vida recebeste os teus bens, e Lázaro de igual modo os males; agora, porém, ele aqui é consolado, e tu atormentado. $26 \mathrm{E}$ além disso, entre nós e vós está posto um grande abismo, de sorte que os que quisessem passar daqui para vós não poderiam, nem os de lá passar para nós. 27 Disse ele então: Rogo-te, pois, ó pai, que o mandes à casa de meu pai, 28 porque tenho cinco irmãos; para que lhes dê testemunho, a fim de que não venham eles também para este lugar de tormento. 29 Disse-lhe Abraão: Têm Moisés e os profetas; ouçam-nos. 30 Respondeu ele: Não! pai Abraão; mas, se alguém dentre os mortos for ter com eles, hão de se arrepender. 31 Abraão, porém, lhe disse: Se não ouvem a Moisés e aos profetas, tampouco acreditarão, ainda que ressuscite alguém dentre os mortos.

26 Este é um modo comum de Gregório citar um autor clássico, neste caso a obra visada é o Fédon de Platão. 
27 "Gregório usa $\sigma \alpha \hat{\alpha} \rho \xi$ e seus derivados quatorze vezes nesta passagem. Ele usa $\sigma \hat{\omega} \mu \alpha$ ou um derivado apenas duas vezes" (Roth, 1992, p. 22).

28 Sobre o conceito bíblico que o corpo é bom: Gênesis 1.31; 1 Coríntios 6.19.

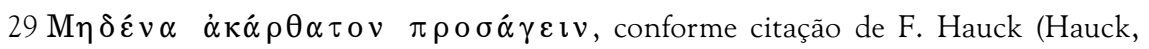
1965, p. 414).

30 Uma das crenças neste sentido é aludida jocosamente em Fédon 81 e - 82 c.

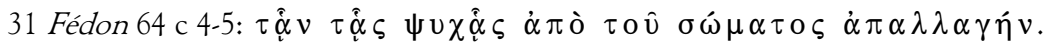

\section{REFERÊNCIAS Bibliográficas}

ANDRADE, R. G. Platão: o cosmo, o homem e a cidade: um estudo sobre a alma. Petrópolis: Vozes, 1993.

BALÁS, D. L. Gregory of Nyssa. In: FERGUSON, E. (ed.). Encyclopedia of Early Christianity. New York \& London: Garland Publishing Inc., 1990.

BERCHMAN, R. M. Neoplatonism. In: FERGUSON, E. (ed.). Encyclopedia of Early Christianity. New York \& London: Garland Publishing Inc., 1990.

BRAUER, J. C. (ed.). The Westminster Dictionary of Church History. Philadelphia: Westminster, 1971.

BROWN, P. Corpo e Sociedade: O Homem, a Mulher e Renúncia Sexual no Início do Cristianismo. Rio de Janeiro: Jorge Zahar Editor, 1990.

BURNET, J. O Despertar da Filosofia Grega. São Paulo: Ed. Siciliano, 1994.

-. Plato's Phaedo. 20 ed. Oxford: Oxford University Press, 1977.

CHERNISS, H. F. The Platonism of Gregory of Nyssa. New York: Burt Franklin, 1971.

COLVIN, C. Plato, Platonism. In: FERGUSON, E. (ed.). Encyclopedia of Early Christianity. New York \& London: Garland Publishing Inc., 1990.

DEMAREST, B. A. In: EDWELL, W. A. (ed.). Enciclopédia Histórico Teológica da Igreja Cristã. São Paulo: Edições Vida Nova, 1990.

DENNING-BOLLE, S. J. Gregory of Nyssa: The Soul in Mystical Flight. Greek Orthodox Theological Review. v. 34, 1989.

DODDS, E. R. Os Gregos e o Irracional. Lisboa: Gradiva, 1988.

FERGUSON, E. Backgrounds of Early Christianity. Grand Rapids: Wm. B. Eerdmans Publ. Co., 1987.

FIGUEIREDO, F. A. Curso de Teologia Patrística III. Petrópolis: Vozes, 1989. 
GALLOP, D. Plato: Phaedo. 2 ed. Oxford: Clarendon Press, 1988.

GONZÁlEZ, J. L. Historia del Pensamiento Cristiano. Miami: Editorial Caribe, 1992. t. 1.

HACKFORTH, R. Plato's Phaedo. Translation with introduction and commentary. Cambridge: Cambridge University Press, 1992.

HAMMAN, A. Os Padres da Igreja. 2 ed. São Paulo: Edições Paulinas, 1985.

HATCH, E. The Influence of Greek Ideas and Usages upon the Christian Church. 5 ed. Peabody: Hendrickson Publishers, 1995.

HAUCK, F. Katharós. In: KITTEL, G. (ed.). Theological Dictionary of The New Testament. Grand Rapids, Wm. B. Eerdmans Publishing Company, 1965. v. 3.

HEGEL, G. W. F. Lecciones sobre la historia de la filosofia. México: Fondo de Cultura Económica, 1955. v. 2.

JAEGER, W. Cristianismo Primitivo e Paideia Grega. Lisboa: Edições 70, 1991.

JEANNIÈRE, A. Platão. Rio de Janeiro: Jorge Zahar Editor, 1995.

KIRK, G. S.; RAVEN, J. E.; SCHOFIELD, M. Os Filósofos Pré-Socráticos: História Crítica e Seleção de Textos. 4 ed. Lisboa: Fundação Calouste Gulbenkian, 1994.

MALHERBE A. J.; FERGUSON, E. Gregory of Nyssa's The Life of Moses. Translation and introduction with notes. New York: Paulist Press, 1978.

MOMigliano, A. De Paganos, Judios y Cristianos. México: Fondo de Cultura Económica, 1992.

MOORE, W.; WILSON, H. A. Gregory of Nyssa's On the Soul and the Resurrection. Translation. In: SCHAFF, P.; WACE, H. (ed.). A Select Library of Nicene and Post-Nicene Fathers of Christian Church. Grand Rapids: 1892. v. 5.

NORRIS, F. W. Methodius. In: FERGUSON, E. (ed.). Encyclopedia of Early Christianity. New York \& London: Garland Publishing Inc., 1990.

OTTO, W. F. Los dioses de Grecia: La imagen de lo divino a la luz del espíritu griego. Buenos Aires: Editorial Universitaria de Buenos Aires, 1976.

. Teofania: El Espitiu de la antigua religion griega. 2 ed. Buenos Aires: Editorial Universitaria de Buenos Aires, 1978.

PACHECO, M.C.C.R.M. Tempo e Criação em S. Gregório de Nissa. Braga: Publicações da Faculdade de Filosofia, 1983.

PALEIKAT, J.; COSTA, J. C. In: PLATÃO. Fédon (Os Pensadores). 3 ed. São Paulo: Ed. Abril, 1983. 
PELLEGRINO, M. Il Platonismo di San Gregorio Nisseno nel dialogo "Intorno all' anima e alla risurrezione", Rivista di filosofia neoscolastica. v. 30, 1938.

PETERS, F. E. Termos Filosóficos Gregos: Um Léxico Histórico. 2 ed. Lisboa: Fundação Calouste Gulbenkian, 1983.

PLATÃO. Fédon: Diálogo sobre a Imortalidade da Alma. Tradução e notas de Dias Palmeira. Coimbra: Atlântida Editora,1975.

REALE, G. Platão e Aristóteles. In: . História da Filosofia Antiga. São Paulo: Edições Loyola, 1994.

ROTH, C. P. Platonic and Pauline Elements in the Ascent of the Soul in Gregory of Nyssa's Dialogue on the Soul and Resurrecction. Vigiliae Christianae. 46, Março, 1992.

TEMPLE, W. Plato and Christianity: three lectures. London: MacMillan and Co. Ltd., 1916.

WRIGHT, J. S. Traducianismo. In: EDWELL, W. A. (ed.). Enciclopédia Histórico Teológica da Igreja Cristã. São Paulo: Edições Vida Nova, 1990. v. 3.

PESTANA, Álvaro César. Plato and Gregory of Nissa.

ABSTRACT: A comparative study of Plato's Phaedo and Gregory of Nissa's On the soul and the ressurrection. An analysis of the historical context, characters and the content of each work. Comparative synoptic study of the two works. Discussion of the philosophic use of religious language and the religious use of philosophy.

KEYWORDS: immortality; dialogue; philosophy; patristics; Plato; Gregory of Nissa. 